\title{
Turkey Post 1980 Coup D’etat: the Rise, the Fall, and The EMergence of Political Islam
}

\author{
Khash Hemmati, Simon Fraser University
}

\begin{abstract}
While it has often been perceived that Kemalist Turkey succeeded in firmly establishing secularization, the Islamist movement that followed the 1980 military intervention questioned the fundamental principles of Mustafa Kemal Ataturk by embracing Islamic identity and Islamic values in the social and public sphere. This paper will examine the rise, the fall, and the emergence of political Islam in Turkey following the 1980 coup de'tat. Following the military intervention of 1980, the level of Islamic activism rose due to state policies during the 1980s and 1990s. It can be observed that the consequences of the Islamic tolerance during the 1980s and 1990s led to the rise and the fall of the Islamic leaning Welfare Party of Necmettin Erbakan. This paper will also explain how the Justice and Development Party (AKP) differed its policies from the Welfare Party, by blending a moderate Islamic identity with a proWestern mentality, to achieve support and stability for Islamist politics.
\end{abstract}

$\mathrm{T}$

The struggle between different kinds of Islamists on one side and the state founded on the principles of Mustafa Kemal Ataturk (1881-1938) on the other, have been a continuous factor in the shaping of Turkey's politics. The foundation of the Turkish Republic effectively pushed Islam out of the political and social arena, and marginalized Islamic actors that posed threats to Kemalist secularism. With the advent of the multiparty system in 1945 and the country's first free and fair multi-party elections in 1950, Islamist groups sided with the Democratic Party, led by Turkey's first democratically elected 


\section{The Rise, the Fall, and the Emergence of Political Islam}

Prime Minister Adnan Menderes (Prime Minister from 1950-1960). Under his leadership, they opened the door for the resurgence of cultural and political Islam. ${ }^{1}$ The policies of Menderes reinstated Arabic as the official language of prayer and supported the expansion of Imam Hatip schools (secondary schools for prayer and sermon leaders), agitating the secular establishment and leading to the first military coup d'état of 1960 and the execution of Menderes in $1961 .^{2}$ The 1960 coup d'état is only one example of the consequences of the attempts by civilian governments in Turkey to enforce policies that defer from the policies of Ataturk's secularism. Nevertheless, Islamic social and political activism continued to grow following the execution of Menderes. In the 1980s, politicians like Turgut Ozal (Prime Minister from 1983-1989; President from 1989-1993) attempted to soften the boundary between Islam and secularism. The state's increasing tolerance of Islam in the 1980s would lead to further military intervention to uphold the importance of the fundamental principles of Ataturk in the face of politicians like Necmettin Erbakan (Prime Minister from 1996-1997), who launched "grass-roots efforts to restore Islam's key role in Turkey." ${ }^{3}$ The three sections of this essay aim to explain: how the level of Islamic activism rose following the military intervention of 1980, due to state policies during the 1980s and 1990s; how consequences of the Islamic tolerance during 1980s and 1990s led to the rise and fall of the Islamic leaning Welfare Party (Refah Partisi, 1983-1998) of Erbakan; and, finally, how the Justice and Development Party (the Adalet ve Kalkinma Partisi or AKP) differed its policies from the Welfare Party in the 1990s to ensure political victory.

\section{The Turkish-Islamic Synthesis-Islamic Tolerance and the 1980} Coup d'état

In the 1970s, Turkey was polarized by intense ethnic, sectarian, and ideological conflicts that were in large measure fueled by a severe economic downturn caused by the 1973 oil crisis and the long-term

1 Hakan Yavuz, Islamic Political Identity in Turkey (New York: Oxford University Press, 2003), 33.

2 Zeyno Baran, Torn Country: Turkey between Secularism and Islamism (Stanford: Hoover Institution Press, 2010), 31.

3 Baran, Torn Country, 140. 
consequences of massive rural-to-urban migrations that had been taking place since the 1950s. ${ }^{4}$ By the late 1970s, Turkey was suffering economically and teetering on the brink of civil war between extreme right-wing groups and their counterparts on the left. In this context, there was a growing fear among secularists that the recent Islamic revolution of Ayatollah Khomeini in Iran would prompt a similar Islamist takeover in Turkey. ${ }^{5}$ On September 6, 1980, a rally was led in Konya by Necmettin Erbakan's National Salvation Party (Milli Selamet Partisi). Individuals marched in Ottoman-style clothing while carrying green flags with Islamic symbols. ${ }^{6}$ Within six days, Turkish military forces led by General Kenan Evren seized power in what became known as the military coup détat of $1980 .^{7}$

In an attempt to reduce social tension and focus on the main political danger, Evren's military forces sought to adopt the policy of "controlled Islam," with the goal of forming a "Turkish-Islamic synthesis," a policy which praised the Islamic interpretation of Sunnism in Turkey for guarding pious Turks from international Islamist movements. ${ }^{8}$ In this section, I will explain how religion was used by the military as a source for an ideology of national unity. These decisions by the Turkish military and government functioned as stepping stones for the Islamists to strengthen their political power and for Islam to regain momentum as a key determinant of Turkish nationalism and politics.

The military forces dissolved parliament, then quickly moved in to purge anyone that was perceived as a "leftist," members of the extreme right, and some of the more prominent Islamists. This included Erbakan, who was banned from running for office for seven years. Post-coup policy thereafter aimed to use and promote Islam as a tool against communism, a threat with which, in the words of Chris Morris, "the military regime which ruled Turkey in the early

4 Yavuz, Islamic Political Identity, 68.

5 The economic crisis was due to a combination factors including: a persistent balance of payments deficit, an industry depended on foreign inputs, and the oil price shocks of the 1970s. For more on the economic crisis of the late 1970s. See: Erik J. Zurcher, Turkey: A Modern State, (New York: I.B. Tauris, 2009), 267.

6 Feroz Ahmad, "Islamic Reassertion in Turkey," Third World Quarterly 10, (1988): 750.

7 Ibid., 750.

8 Baran, Torn Country, 140. 


\section{The Rise, the Fall, and the Emergence of Political Islam}

1980s was obsessed." ${ }^{\text {B }}$ By using institutions and symbols of Islam as a counterweight to the Marxist organizations and Leftist movements, the military encouraged the fusing of Sunni Islamic values with national goals, in the sense that the military government planned to foster a co-opted and less political Islam to confront a muchexaggerated leftist threat. ${ }^{10}$ General Evren valued the "rational" nature of Islam ${ }^{11}$ and he proposed that there was an enlightened Islam that promoted modernity, was open to change and secularism, and could act as social cement for unifying the Turkish state against what he felt were the Kurdish separatist and Marxist threats. ${ }^{12}$ For Evren, Islam "was an element in the service of the nation and nationalism rather than as an autonomous force to compete with either secularism or nationalism." ${ }^{13}$ Fundamentals of Turkish Islam were used by military leaders to legitimize temporary rule and to attempt to unite the nation under its guidelines.

Religion was imbued with the role of providing social solidarity by the military's reforms, which in turn would pave the way for the strengthening of political Islam and the re-emergence of Islam as a key factor in Turkish nationalism and politics. Compulsory religious education for all primary and secondary schools was introduced, while many religious and Koranic schools were expanded and a mosque building campaign was undertaken. ${ }^{14}$ At the same time, the military formed the Department of Propagation as a new department in the Directorate of Religious Affairs, and used this new organization as a platform for their fight against Kurdish nationalism and Marxistnationalist ideologies which were popular in southeast Anatolia. ${ }^{15}$ These reforms engaged public religious education as religious television programs increased and Imam Hatip schools expanded from 72 in 1970 to 382 in $1988 .{ }^{16}$ The expansion of religious schools

9 The emphasis on traditional values, a combination of Turkish nationalism with religion, was used by the secular guardians in the military as a counterweight against Marxism. See Chris Morris. The New Turkey: The Quiet Revolution on the Edge of Europe (London: Granata Publications, 2005), 72-73.

10 Hakan Yavuz, Islamic Political Identity, 69.

11 Ibid., 70.

12 Ibid.

13 Ibid., 71.

14 Chris Morris. The New Turkey, 73.

15 Hakan Yavuz, Islamic Political Identity, 70.

16 Zeyno Baran, Torn Country, 36. 
increasingly allowed graduates to find positions in the government bureaucracy. ${ }^{17}$ The military leadership's efforts to open Islam to the social, public, and political arenas had results contrary to their vision, in that Islam-focused politicians, like Ozal, Erbakan, and Recep Tayyip Erdogan, who eventually became the influential leader of the AKP, would come to play dominant roles in Turkish politics. In 1980, the opportunity to "invent a more religious Turkish polity" arrived, and it was with this that the military helped the Islamist to attract the votes of the discontented. ${ }^{18}$

The outcome of the 1983 parliamentary elections, which marked the return to a parliamentary democracy, albeit a carefully circumscribed one, sharply deviated from the victory that the Turkish military had expected. ${ }^{19}$ The results of the election would lead to the rise of a leader who played a significant role in allowing Islam to regain momentum as a key determinant of Turkish nationalism and politics. The Motherland Party (Anavatan Partisi) of Turgut Ozal, which was openly criticized by the military regime, won the election over the military supported Populist Party. ${ }^{20}$ Ozal, who became the Prime Minister and later the President of the Republic, was a former Islamist with Kurdish roots who had openly declared himself to be a practicing Muslim. ${ }^{21}$ Ozal was the first Turkish president to undertake the haj to Mecca, and he stood against some military decisions, as when he vetoed the appointment of a new chief of the general staff. ${ }^{22}$ The failure of the military leaders to perceive the Motherland Party as a threat led to the rise of Ozal and further strengthened the Islamists' position in Turkish politics. Although Ozal mostly acted within the framework set by the military, he was perceived as the man who officially legitimized the "radically new perspectives on the role of Islam and the Ottoman heritage in contemporary Turkish society."23

17 Ibid.

18 Sam Kaplan, The Pedagogical State: Education and the Politics of National Culture in Post-1980 Turkey (Stanford: Stanford University Press, 2006), 44.

19 Sabri Sayari, "The Changing Party System," in Politics, Parties, and Elections in Turkey, ed. Sabri Sayari and Yilmaz Esmer (London: Lynne Rienner Publishers, 2002), 16.

20 Yavuz, Islamic Political Identity, 75.

21 Oliver Roy, “Turkey: A World Apart, or Europe's New Frontier?," in Turkey Today: A European Country, ed. Oliver Roy (London: Anthem Press, 2004), 18. 22 Morris, The New Turkey, 44.

23 Yavuz, Islamic Political Identity, 75. 


\section{The Rise, the Fall, and the Emergence of Political Islam}

Ozal's years in power nurtured the Islamic identity and strengthened Islamic values in the social and public sphere. In the 1983 elections, Ozal appealed to what he termed "the long repressed Muslim identity of Turks," and followed up by claiming that, under his rule, the political leadership would be more sensitive to religious issues. ${ }^{24}$ Ozal's party encouraged owners of small capital in the smaller cities and towns in Anatolia to invest their money in market-oriented businesses. ${ }^{25}$ Ozal's notion of liberalism and free market capitalism within Muslim parameters allowed for the increasing tolerance of Islam, and "contributed to the expansion of the public sphere in multiple directions." ${ }^{26}$ Ozal's reforms were mainly to the benefit of entrepreneurs based in Anatolia who had been marginalized by the previous governments which tended to be closely allied with the elite of Turkey's secular business leaders like the Koc and Sabanci families. Ozal's economic policies were favourable towards and greatly supported by the Islamist forces that thrived under his leadership conditions. Ozal's government introduced Turkey to Islamic finance and banking according to sharia requirements and this led to a large influx of capital investments from oil-rich countries like Saudi Arabia. ${ }^{27}$ This oil money was then distributed to new Islamic groups via well-funded financial circles. Ozal's policies provided the legal foundations for charitable donations used for religious purposes. ${ }^{28}$ The increased interaction with other Islamic business communities and the restoration of historic connections by Islamic groups marked a change from pre-1980 Turkey. Ozal's anti-bureaucratic and free market policies were supported by the bourgeoisie of large Turkish cities, as well as the small-scale business owners who supported Islamic symbols and ethics as a weapon against state intervention in the economy and big industrialists who enjoyed state patronage. ${ }^{29}$ These factors contributed in the formation of Islamic associations like The Independent Businessmen and Industrialists Association (Mustakil

24 Baran, Torn Country, 39.

25 Sefa Filmflek, "New Social Movements in Turkey Since 1980," Turkish Studies 5, (2004): 121.

26 Berna Turam, Between Islam and the State: The Politics of Engagement. (Stanford: Stanford University Press, 2007), 49.

27 Baran, Torn Country, 39.

28 Yavuz, Islamic Political Identity, 89.

29 Ibid. 


\section{Khash Hemmati}

Sanayici ve Isadamlari Dernegi, MUSIAD), which offered small business owners a critical voice in engaging in economic discourse and business. ${ }^{30}$ During the Ozal period, a new type of bourgeoisie emerged which closely identified with "Islamically inclined segments of the populace" and by the mid-1980s the transformation of Islamic organizational networks led to a major increase in pro-Islamic corporations in Turkey, where more than 4,000 corporations were identified as pro-Islamic. ${ }^{31}$

It becomes clear that, following the 1980 coup détat, there was a new window of opportunity for Islamist groups to assert themselves in order to gain political power and influence in Turkish nationalism and politics. Prior to the 1980s, Islam was officially isolated from politics and the secular-supporting military repressed leaders like Menderes who supported Islamic foundations. With the 1980 military takeover of the government, the military did not view Islam as the main threat to the values of Secular Republic, but instead saw Leftist movements and communism as the threat against Kemalist secularism. While using Islam as a cementing force for uniting Turkish society against Leftist threats, the military leadership in the early 1980s became tolerant of Islamic principles, allowing Islamists to gain political power and influence.

\section{Islamism and Its Limits: The Rise and Fall of the Welfare Party}

Following the 1980 coup detat, the Turkish state permitted Islamist groups to participate in the country's economic and political spheres. Islamist groups were consequently incorporated into state plans. Following Ozal's death in 1993, Turkey entered a new period of economic and political instability, causing dissatisfaction amongst the population. This worked to the advantage of Erbakan's Welfare Party. ${ }^{32}$ The strengthening of power and the rising numbers of Islamist groups under Ozal's leadership produced votes for the Welfare Party in the 1994 municipal elections. The Welfare Party became a major

\section{Ibid.}

31 Ibid., 91.

32 Baran explains that the Turkish population was weary of the corruption scandals surrounding Ozal's time in office and of the persistent disputes between Turkey's centre-right and centre-left factions. See: Zeyno Baran, Torn Country, 40-41. 


\section{The Rise, the Fall, and the Emergence of \\ Political Islam}

representative of political Islam, first coming to power at the level of local governments and later in the national government with the True Path Party (Dogru Yol Parti) in 1996. ${ }^{33}$ The Welfare Party utilized its grassroots mobilization by reaching out to the urban poor, and served people across the lines of class, occupation and gender. However, the success of the party sparked "widespread public fear and suspicion by the state and secularists." ${ }^{4}$ This section explains how the tolerance of Islam by the military government of 1980-83 and Ozal's leadership until 1993 would lead to the utilization of Islamic ideas by the Welfare Party, bringing them into power. This section will also address the accusations against the Welfare Party of activities that challenged the principles of the Turkish state. These charges resulted in an indirect military intervention against the party in what became known as the soft coup of 1997.

The rise of the Welfare Party can be associated with the state tolerance of Islamic principles under the military rule's notion of "Turkish-Islamic Synthesis," as well as Ozal's integration of Islamic values in the national political culture, which led to the rise of Islamist groups. The increased visibility of Islam and the influence of Islam and religious activism in Turkish politics resulted in the increased popular appeal of the Welfare Party. ${ }^{35}$ Following the 1983 election, the political elite under the eyes of the military leadership decided that Islamists needed to be integrated into the Turkish system in order to eliminate the Leftist threat. It was decided that this integration could only be achieved by accepting what Hakan Yavuz calls "soft Islam." ${ }^{36}$ This form of Islam, it was thought, would be closely monitored and tamed, and "subsequently the Islamist groups entered the system through the expansion of educational opportunities, economic activity, and party politics." 37 Thus, by inviting the Islamist groups into the system, the secular state thought it could maintain its hold on the religious movements while using their religious notions to combat the Leftleaning Marxist groups.

During the 1990s, the Islamic challenge brought success for the

33 Filmflek, "New Social Movements," 122.

34 Turam, Between Islam and the State, 49.

35 Sayari, "The Changing Party System," 19.

36 Yavuz, Islamic Political Identity, 214.

37 Ibid. 
Welfare Party in both national and municipal elections. ${ }^{38}$ With the sudden death of Ozal in 1993, the Welfare Party was able to win over the traditional urban voters by promising them an end to corruption by imposing a "just order" rooted in Islamic traditions. ${ }^{39}$ Voters supported the party's embrace of Islam because "it made it seem morally "purer" than the discredited parties of the center-left and center-right." ${ }^{40}$

Studies attribute the popularity of the Welfare Party to a rise in religiosity and religious values. ${ }^{41}$ Under the military rule and later under the leadership of Ozal, first as Prime Minister then as President, religion was highly valued and religious schools were greatly expanded to drive home these values. Although the supporters of the Welfare Party were not necessarily Islamists in the political sense, they were moved by religious motives. ${ }^{42}$ This explains the support for the Welfare Party in municipal elections by the rural voters that had migrated to the cities, since this group traditionally considered Islam "a core element of their identity." 43

In the 1960s and 1970s, mass migrations to the cities occurred due to increased poverty in the countryside as a result of state policies that favoured the mechanization of agriculture. ${ }^{44}$ However, the rural population failed to integrate into their new surroundings in the cities. The low-income newcomers needed low-cost housing which led to the development of squatter houses, known as gecekondu, often on state land. ${ }^{45}$ Among these squatter towns, Islam "became a means of communication and alliance formation," which Erbakan utilized to gain votes. The Welfare Party's supporting base grew in the poor neighbourhoods and squatter towns, and the Welfare Party used religious organizations and foundations to help the poor, gaining

38 Fuat Keyman, "Introduction: Modernity and Democracy in Turkey," in Remaking Turkey: Globalization, Alternative Modernities, and Democracy, ed. Fuat Keyman (Plymouth: Lexington Books, 2007), xxiii.

39 Baran, Torn Country, 41.

40 Ibid.

41 Yilmaz Esmer, "At the Ballot Box: Determinants of Voting Behavior," in Politics, Parties, and Elections in Turkey, ed. Sabri Sayari and Yilmaz Esmer (London: Lynne Rienner Publishers, 2002), 93.

42 Ibid.

43 Baran, Torn Country, 41.

44 Yavuz, Islamic Political Identity, 83.

45 Ibid. 


\section{The Rise, the Fall, and the Emergence of Political Islam}

popular support for their political movement. ${ }^{46}$

The policies of Erbakan's Welfare Party demonstrated the extreme form of the Turkish-Islamic synthesis, by illustrating that political Islam was still limited and under the control of military leaders who valued Ataturkism. By the time Erbakan's party was winning municipal and national elections, there was a sharp division between secular and Islamist sociocultural lines; the Welfare Party became one of the main platforms for "political Islam to articulate its demands within the public sphere." ${ }^{47}$ Erbakan's victory set the stage for him to challenge the secular establishment through his Islamist policies, but his call for the establishment of an Islamic state caused extensive public fear and suspicion. ${ }^{48}$ Erbakan's actions following his 1996 election victory included: hinting that he might pull Turkey out of NATO; forming a new, NATO-style alliance amongst Islamic nations; threatening to terminate Turkey's long-standing bid to join the European Union; and vowing to overturn the legislation forbidding women to wear the hijab while working in state buildings. ${ }^{49}$ Erbakan's propositions directly challenged Ataturk's policy of aligning with the West, and his suggestion of attempting to legalize Islamic clothing in state buildings was a further blow to Ataturk's state policies of secularism, which promoted western modernity and clothing. Although Ozal also valued Islamic symbols and principles and expanded openings for Islam under the notion of the Turkish-Islamic synthesis, unlike Erbakan, he embraced Western ideas, demonstrated through his support for the Americans against Saddam Hussein in the first Gulf War in $1991 . .^{50}$

It became clear that the Turkish military, as the supporters of the fundamental principles of Ataturk, were not going to go along with Erbakan's radical plans for an Islamic revival.

On February 28, 1997, in what became known as the "February 28 Process," the National Security Council (an advisory body composed of top military commanders, the Prime Minister, and several cabinet

46 Haldun Gulalp. "Political Islam in Turkey: The Rise and Fall of the Reftah Party," The Muslim World 89, (1998): 35.

47 Yavuz, Islamic Political Identity, 214.

48 Turam, Between Islam and the State, 49.

49 See Ann Louise Bardach, "A Real Turkey," The New Republic 217, (July 7, 1997): 17.

50 Baran, Torn Country, 40-41. 
members) came to the conclusion that measures were necessary to curb the pro-Islamist activities of the Welfare Party. ${ }^{51}$ The military presented Erbakan's government with a list of measures that were intended to curb his Islamist activities and Erbakan was left with no choice but to accept the military's measurements. ${ }^{52}$ While Erbakan initially agreed to the imposed measures, he feared that restricting the Islamist media and closing private Koranic schools would alienate his party's grassroots support. ${ }^{53}$ With increasing public pressures led by the military, which used public meetings to warn of the dangers of Islamic fundamentalism, Erbakan resigned as prime minister on June 18, 1997; the Welfare Party was subsequently dissolved and Erbakan was banned from politics for five years. ${ }^{54}$

\section{Successful Campaign by Dissociation: The Victory of the AKP}

Following the fall of the Welfare Party, "alternative codes of conduct" were formulated between the state and the Islamic politicians..$^{55}$ The primary role of the Turkish military can be defined by looking at Article 35 of the Internal Service Act of 1961, which states that the role of the military is to "safeguard and defend Turkish territory and the Republic of Turkey as designated by the constitution." ${ }^{56}$ Since the Kemalist principles and doctrine are fully incorporated into the constitution, the Turkish military then sees itself as the protector of those principles and doctrines. ${ }^{57}$ In the final section of this paper, I argue that, although the founders of the Justice and Development Party (AKP), registered in 2001, have their roots in the Welfare Party, they had to change their political actions in order to avoid the fate of Erbakan's party. The key founders of the AKP, Recep Tayyip Erdogan, Abdullah Gul, and Bulent Arinc, had all represented separate currents within Erbakan's wing. ${ }^{58}$ In order to gain legitimacy and the approval of the state's elites, like the military leadership, these politicians had

51 Gulalp, "Political Islam in Turkey," 39.

52 Gareth Jenkins, “Muslim Democrats in Turkey?," Survival 45, (2003): 50.

53 Ibid., 51.

54 Ibid.

55 Turam, Between Islam and the State, 134.

56 Yavuz, Islamic Political Identity, 245.

57 Ibid.

58 Zeyno Baran, Torn Country, 45. 


\section{The Rise, the Fall, and the Emergence of Political Islam}

to keep their policies different from that of Erbakan's Welfare Party. The 2002 elections, which brought the AKP to power with 363 out of the 550 seats in the parliament, represented an historical break, as a socially Muslim party was now given the opportunity to restructure the political landscape and expand the public sphere. ${ }^{59}$

The AKP leaders, unlike Erbakan's Welfare Party, appreciated Ozal's policies and aimed to shape their own policies to match his. The AKP's most prominent figure, Erdogan, came to identify himself with Ozal's policies as a way for society to reactivate Ozal's legacy, and utilized this association to promote his own policies. ${ }^{60}$ Erdogan became the only leader to identify himself with the spirit of both Menderes in the 1950s and Ozal in the 1980s; by invoking Ozal's legacy, Erdogan was able to form a public policy that demonstrated the compatibility of overt religiosity with what the state considered tolerable. ${ }^{61}$ Erdogan was able to redefine the Islamic identity of Turkey and to distinguish that identity from Erbakan's notion of Islamic identity. Prior to the formation of the AKP, Erdogan had publically stated "praise to god; we are all for sharia" and went further by saying "one cannot be secular and a Muslim at the same time. You will either be a Muslim or a secularist." ${ }^{2}$ The statements made by Erdogan illustrate his views as a former member of the Welfare Party, as they resemble Erbakan's radical Islamic views. Erdogan and the AKP founders recognized that a patient approach was needed to gradually build support for a greater political role for Islam within the structures of the Turkish Republic. ${ }^{63}$ In order to achieve support and stability for Islamist politics, the AKP founders “thus decided to break with Erbakan's confrontational approach." 64

The AKP founders were able to appeal to both Western supporters and Islamist supporters by avoiding the policies of Erbakan, which insisted upon Islam as the guideline for Turkish politics. The adoption of a pluralist aspect allowed the AKP leaders to appeal to a wide range of supporters. According to Yavuz, the AKP leaders were more exposed to European ideas, while also maintaining a sense of clearly defined

59 Yavuz, Islamic Political Identity, 256.

60 Ibid.

61 Ibid.

62 Baran, Torn Country, 45.

63 Ibid., 46.

64 Ibid. 
Islamic identity. ${ }^{65}$ Accordingly, their centre-right political party appealed to Islamists who were willing to work within the democratic system, as well as to the liberal democrats who wanted further social, political and economic freedoms. ${ }^{66}$ This then explains why the AKP leaders based their politics on that of Ozal rather that of Erbakan, since Ozal's Motherland Party was able to integrate the business community, liberal democrats and the Islamists. ${ }^{67}$ The pluralist approach was successful, as the supporters that were attracted to the AKP were drawn to factors other than the party's views on religion; this explains why two-thirds of the people who voted for the AKP in their first election had never voted for Islamist parties before. ${ }^{68}$

One major difference between Erbakan's politics and those of Erdogan is that the AKP leadership had a desire to take Turkey into a stronger relationship with Europe. Immediately following their national electoral victory in 2002, the AKP leadership worked on the project of fulfilling the European Union criteria for beginning accession talks. ${ }^{69}$ The AKP saw the EU criteria for democratization, human rights and state reform as "an echo of its own struggle against the army and the Islamists over the past 20 years." ${ }^{\prime 70}$ The normative base of the AKP consists of a Turkish-Islamic synthesis, which promotes a new global discourse of human rights and democracy, representing the Westernization of Islamism in Turkey. ${ }^{71}$ When the accession talks began in 2005, the "AKP seemed legitimized as a proWestern political party pursuing Turkey's traditional foreign policy," and EU support among "pro-Western liberal Turks" had increased significantly.

65 Yavuz, Islamic Political Identity, 258.

66 Baran, Torn Country, 46.

67 Ibid.

68 Morris, The New Turkey, 70.

69 Baran, Torn Country, 126.

70 Roy, "Turkey: A World Apart," 25.

71 Yavuz, Islamic Political Identity, 261. 


\section{The Rise, the Fall, and the Emergence of Political Islam}

\section{Conclusion}

In conclusion, the 1980 coup détat was a turning point in Turkish nationalism and political affairs. While the Turkish military censored some public references to Islam, at the same time they used religion as a means to appeal to national unity after the military intervention of 1980. Following the military coup d'etat of 1980, a new window of opportunity emerged for the Islamists groups to reassert themselves. Turgut Ozal successfully utilized the military's goal of Turkish-Islamic synthesis to soften the boundary between Islam and secularism. Following Ozal's death in 1993, the Islamist Welfare Party was ready to take advantage of the more liberalized society that Ozal had put together. Erbakan's victory in the mid 1990s brought Islamism to power. The policies by Erbakan's Welfare Party demonstrated the extreme form of the Turkish-Islamic synthesis, which accordingly also demonstrated the limits of political Islam, as the soft coup of 1997 brought an end to his leadership. The military leaders of the Turkish Republic illustrated that they were unwilling to accept a radical Islamist agenda in the political sphere. As the winner of the 2002 national elections, the AKP represented a transformation of the Islamic groups in Turkey with an increased sense of ideological moderation. ${ }^{72}$ By blending a moderate Islamic identity with a proWestern mentality, the AKP aimed for social integration and stability. By avoiding radical Islamist policies, the AKP leaders have managed to gain the trust of segments of the Turkish military and the civilian population since they acknowledge that the government has to pursue a secular, and more specifically, a pro-Western political agenda. The AKP have promoted the image that, with the right balance between policies that are both Islamic and pro-Western, various segments of the Turkish population can utilize the secular political framework.

72 Ali Resul Usul, Democracy in Turkey: The Impact of EU Political Conditionality, (Abingdon: Routledge Taylor \& Francis Group, 2011), 158. 


\section{Khash Hemmati}

\section{Bibliography}

Ahmad, Feroz. "Islamic Reassertion in Turkey." Third World

Quarterly 10, 2 (1988): 750-769. http://dx.doi.org/10.1080/01436598808420080

Baran, Zeyno. Torn Country: Turkey between Secularism and Islamism. Stanford: Hoover Institution Press, 2010.

Bardach, Ann Louise. “A Real Turkey: Tansu Ciller's Manipulative Rise to Power." The New Republic 217, 1 (July 7, 1997): 1619.

Esmer, Yilmaz. "At the Ballot Box: Determinants of Voting Behavior." In Politics, Parties, and Elections in Turkey, edited by Sabri Sayari and Yilmaz Esmer, 9-32. London: LynneRienner Publishers, 2002.

Filmflek, Sefa. "New Social Movements in Turkey Since 1980.” Turkish Studies 5, 2 (2004): 111-139. http://dx.doi.org/10.1080/1468384042000228611

Gulalp, Haldun. "Political Islam in Turkey: The Rise and Fall of the Refah Party." The Muslim World 89, 1 (1998): 22-41. http://dx.doi.org/10.1111/j.1478-1913.1999.tb03667.x

Jenkins, Gareth. “Muslim Democrats in Turkey?” Survival 45,1 (2003): 45-66. http://dx.doi.org/10.1093/survival/45.1.45

Kaplan, Sam. The Pedagogical State: Education and the Politics of National Culture in Post-1980 Turkey. Stanford: Stanford University Press, 2006.

Keyman, Fuat. "Introduction: Modernity and Democracy in Turkey." In Remaking Turkey: Globalization, Alternative Modernities, and Democracy, edited by Fuat Keyman, xv-xxviii. Plymouth: Lexington Books, 2007.

Morris, Chris. The New Turkey: The Quiet Revolution on the Edge of Europe. London: Granta Publications, 2005. 
The Rise, the Fall, and the Emergence of Political Islam

Roy, Oliver. “Turkey: A World Apart, or Europe's New Frontier." In

Turkey Today: A European Country, edited by Oliver Roy, 11-25. London: Anthem Press, 2004.

Sayari, Sabri. “The Changing Party System." In Politics, Parties, and Elections in Turkey, edited by Sabri Sayari and Yilmaz Esmer, 9-32. London: Lynne Rienner Publishers, 2002.

Turam, Berna. Between Islam and the State: The Politics of Engagement. Stanford: Stanford University Press, 2007.

Usul, Ali Resul. Democracy in Turkey: The Impact of EU Political Conditionality. Abingdon: Routledge Taylor \& Francis Group, 2011. http://dx.doi.org/10.4324/9780203847381

Yavuz, Hakan. Islamic Political Identity in Turkey. New York: Oxford University Press, 2003.

Zurcher, Erik J. Turkey: A Modern State. New York: I.B. Tauris, 2009. 